\title{
BRITISH FICTIONS AFTER DEVOLUTION: William BOYD's Culinary ARTS
}

\author{
Dougal McNeill*
}

Where are we to place William Boyd? This question, vexed enough for most novelists, given the variety and transformation in any life and collection of works, takes on added complexities in Boyd's case because the obvious answer-he is a contemporary British novelist-introduces follow-up questions of a currently unanswerable nature. Where is Britain; and what does it mean, in the twenty-first century, to be a British novelist? These definitions, for much of the nineteenth and twentieth centuries, seemed not to matter greatly, as Britishness, in its local national variations, provided an ambiguous synthesising terrain for Scottish, Welsh and English writers. National identity in Scotland, Wales and England could, through the long reign of the British Empire, be assimilated more-or-less successfully into a broader British identity: British novelists were, quite simply, novelists from Britain. In the twentyfirst century, with devolution and moves to full independence on the ascendant in Scotland, greater calls for Welsh autonomy, and the fact of multiculturalism a lived reality in English cities like Birmingham, London and Manchester, the question of what it is that makes an author British becomes rather more interesting, and rather more vexed.

William Boyd, a Scottish author born in Africa and long resident in London, fits uneasily in accounts of the regionalisation or "devolution" of English literature." This may explain why,

* Dougal McNeill teaches in the English Programme, Victoria University of Wellington. He is the author, with Charles Ferrall, of Writing the 1926 General Strike (Cambridge, 2015) and is co-editor, also with Charles Ferrall, of the 1920-1940 volume of the Cambridge series British Literature in Transition. 
despite his critical and commercial success, Boyd has received scarcely any scholarly attention: he is a British author in the era of Scottish writing. Scottish literature, after all, provided the imagination of the era of Union; the Anglo-Scottish novelist, nowadays, is a rather more endangered species. Tracking the movements of one example may provide insights into these questions of literature, language, and location. My purpose here is not to suggest Boyd is central to this particular story. There are other writers, Alan Massie and his historical novels most notably, pursuing British literary projects still, and to perhaps greater effect. Boyd figures in what follows, rather, as an example or a symptom, a sampling from the world of British fiction as it circulates now.

But then where is Britain in Boyd's work? It was not until the turn of the century, with Armadillo (1998) and its account of financial dealings and family dramas in London, that Boyd set a novel in Britain. Scottish literature, from Smollett to Spark, has spent a good deal of time abroad, to be sure; Boyd takes this to boisterous new limits. Earlier works had covered Africa-from $A$ Good Man in Africa (1981) to the east African settings of the First World War novel An Ice-Cream War (1982) and the tale of scientific research and human relations in Brazzaville Beach (1990)_Los Angeles and Manila in The Blue Afternoon (1993), and continental Europe in The New Confessions (1987). It was only in the twenty-first century, just as the Scottish Renaissance was reaching its full creative maturity, that Boyd made London the centre of his own fiction. His novels are restless, globe-trotting, varied creations, taking in everything from chimpanzee research to the film business, to war-time spying and conspiracies in the global pharmaceutical industry. The conventions of literary criticism train us to look for patterns, order, consistency, and to group authors under national labels. But Boyd's thematic and stylistic eclecticism, as much as his uncertain connection to national location, makes this sort of approach difficult.

This very eclecticism raises a further question: what does it mean to discuss the British novel now as a separate genre or group? Publishers and booksellers group "literary" fiction apart from "genre" works in the detective, science-fiction and romance traditions, but genre-crossing trends in recent writing-to say 
nothing of critical examination of this vague term "literary"undermine the finality of these divisions on the bookshop floor. If bookshops and libraries in Scotland recognise the vitality-and viability - of the nation's literary tradition, the rest of us are kept searching through the placidly unionist discriminations of the Library of Congress classification systems. In the libraries, if nowhere else, British fiction remains. Boyd is a rewarding writer to read and think with, then, because his novels raise questions relevant to wider trends in contemporary fiction: what are we to make of his turn to historical fiction? What are the relations between these novels' globalised settings and their national (or, with devolution in Scotland, post-national) traditions and affiliations? What makes these "literary" fictions? What does it mean to talk about Britishness in literature in the twenty-first century? Boyd himself encourages us, in light-hearted and oblique ways, to read with these questions in mind: the first chapter of Restless (2006) announces our journey "into the heart of England."2

Perhaps the distinction between Scottish, British, and globalised fiction is a false one. After all, as Robert Young has shown, British and English identities were, in the nineteenth century, produced as much abroad - in the settler colonies of the Empire-as they were at home, and many a Scottish writer, from Carlyle to Hume, was put in the service of imagining Britishness from Canada to New Zealand. English fiction, too, has long had an international-not to say imperial-reach, with authors such as Graham Greene and Evelyn Waugh setting their fiction in distant locations and amongst foreign and bewildering events. ${ }^{3}$

What James Wood calls "the particular English inflection" of understated humour has been developed by Scottish authors among others, and so Boyd's own blurred boundaries take up older hazy distinctions. ${ }^{4}$ His novels hint at this relation with their parade of quasi-Scots, Scottish figures and themes hovering in the background, as with Ordinary Thunderstorm's whisky-drinking doctor, "a Scot who did not have a Scottish accent". Characters are often quizzed about their origins, with Logan Mountstuart, narrator of Any Human Heart, quizzed if he had "any Scottish blood?" "Scots are very keen to establish this fact from the outset". Other novels point to Scottish names ("is that Scottish?") and Scottish 
ancestors. Most obviously, too, Boyd's Solo (2013), a James Bond story produced in cooperation with the Ian Fleming estate, takes up a fictional character famous, in both his literary and film manifestations, as a symbol of Britishness. ${ }^{5}$ Bond's own ambiguities fit Boyd's nicely: Scottish on his father's side, as readers learn in You Only Live Twice (1964), and played to most acclaim by a Scottish actor, Sean Connery, Bond's very Britishness is caught up with an insistent Scottish presence. Two academics writing about Bond have called him "a site for the elaboration ... of a mythic conception of nationhood" and a character whose "role in organising and co-ordinating popular responses to the changing fate of the nation ... has perhaps been the most vital of the diverse functions he has fulfilled." It may well be, then, that, in this gesture that seems to turn from the questions of national identity most decisively-for what could be less serious than a spy thriller?-Boyd in fact produces his most sustained exploration of Britishness. Having cast doubt in his critical writing on whether "there is such a genre" as Scottish fiction, Boyd's novels assert their connections to it on the sly. ${ }^{7}$

Slyness indicates other affiliations with this older line in Scottish fiction. Boyd has always been a fair distance from the postmodernist "historiographic metafictions" fashionable through his youth, and a fair way from their scepticism about plotting, narrative coherence and meaning-making; his own novels are much closer to "ripping yarns" than instances of "incredulity toward metanarratives." ${ }^{8}$ For all that, however, his novels of the last decade display a very traditional enthusiasm for whimsy and play. James Bond in Solo reads Graham Greene's The Heart of the Matter (1948) while on his flight to Africa, drawing attention to his-and Boyd's - links to this earlier English representation of Africa and shady business dealing. A single character-Sam M. Goodforthappears across all Boyd's novels as, variously, a rival novelist, a "temporary major" in the First World War, the author of The Hollow Mountain, a gun-shop owner, a medical researcher, a journalist, and a marine surveyor. ${ }^{9} \mathrm{He}$ is, in each appearance, incidental, almost irrelevant to the plotting of each novel, and could well pass unnoticed on any first reading. His reappearance, 
however, links each novel together without making any explicit comment on what it is this linkage involves.

Boyd enjoys the shapeless and the uncertain, having used fictionalised autobiography, in The New Confessions (1987) and fictionalised journals, in Any Human Heart (2002) to draw attention to the ways narrative form imposes order and finality on what is really "that collection of selves that form us, the individual human being ... a true journal presents us with the more riotous and disorganised reality". ${ }^{10}$ In his non-fiction Boyd has used alphabetized lists to similar effect, introducing, for example, his play Longing (2013) with an A-Z of words connected to Chekhov's life and work. It is for the reader to make connections. This is one part canny business sense- "writers recycle avidly," Boyd tells us; "nothing is lost" — and one part thematic musing, a reminder of the centrality of play and mischief in the experience of art, those elements the Canadian critic Northrop Frye celebrated as drawing from the traditions of the riddle, "ciphers, acrostics, rebuses, concrete and shape poetry." 12

Nat Tate: An American Artist 1928-1960 (1998) is probably the cheekiest of Boyd's contributions to this whimsical, humourous and mischievous tradition. Although advertising its account of "Nat Tate's life and times" as "full of ambiguities and contention", Nat Tate was first published as a "straight" biography of an unjustly-forgotten American artist. An abstract expressionist who destroyed most of his work before his own suicide (and whose body was never found), Tate was introduced to the world on April Fool's Day, 1998, when Boyd, David Bowie and other collaborators launched the "biography" with readings in New York. A week later an article in the Independent revealed the whole thing to be a hoax. Tate went on, with several other characters in his "biography" to lead a second fictional life in Any Human Heart. The narrator of that novel gets to know him when working as an art dealer in New York, and pursues an affair with Tate's dealer. Fiction, hoaxing and double-hoaxing dance together through Boyd's oeuvre. ${ }^{14}$

A shift in Boyd's work over the last fifteen years, however, has seen these notes of whimsical interrogation replaced with a more self-conscious and serious treatment of "History" as theme 
and material, in a series of what one reviewer called "moody thrillers." 15 The novels of the last decade take up Big Themes: war, revolution, terrorism (Any Human Heart), the Cambridge spies, Cold War betrayals, shifting loyalties in the Second World War (Restless), the politics of pharmaceutical big business, academic intrigue and the realities of homelessness (Ordinary Thunderstorms), the First World War and psychoanalysis (Waiting for Sunrise). Espionage, spy rings and betrayal are common components. These join in the last decade's more general "explosion in the sales and popularity of novels set in the past,"16 to be sure, but it is not always clear what is being done with this historical material. Boyd presents a glamourous, enjoyably consumable version of the past, a kind of fictional equivalent of the heritage industry in historic homes or the vogue for shows like Downton Abbey on television. The reader realises, long before the narrator need tell her, that the man in a Vienna café in 1913 who is "in his late fifties" with "fine greying hair combed flat against his head" and a beard "completely white and trimmed with finical neatness" is Sigmund Freud. ${ }^{17}$ The "historical" in these historical novels comes with a form of narratorial heavy breathing, as when we are told of Lysander Rief, hero of Waiting for Sunrise,

drinking beer here in the middle of summer in England in 1914, he suddenly felt a stillness creep up on him as if he were suffering from a form of mental palsy - as if time had stopped and the world's turning, also. It was a strange sensation-that he would be for ever stuck in this late June day in 1914 like a fly in amber- the past as irrelevant to him as the future ${ }^{18}$

Never such innocence again! This is not Henry James's "palpable imaginable visitable past" 19 so much as a kind of gesturing at something called History. Readers know, from countless novels, films and television serials, the story of the lead-up to war and the summer of 1914; this moment of a character reveling in their own certainty provides us with some foreshadowing while also reassuring us of our own historical literacy and sophistication. History, in Boyd's recent fictions, is a kind of glamorous backdrop 
or waiting room. A great deal of drinking gets done in these novels, each sophisticated location and high-class café or hotel described, and we are allowed a touristic visit into the past.

One way of placing Boyd, therefore, involves linking his turn to writing historical thrillers with wider patterns in what is happening to writing described as "literary fiction." Boyd's fictions assume an educated audience. Their topics draw on recent history and world events, and their epigraphs gesture at namesHemingway, Sophocles, Henry James, Proust, Wordsworthfamiliar to someone with a literary education. Their form, however, draws on the easily consumable and intellectually undemanding conventions of the thriller: there are surprising revelations and chase sequences (Waiting for Sunrise's final revelation of the true spy and villain); climactic encounters (Ordinary Thunderstorms' final confrontation with Big Pharma); and shock reversals and erotic betrayals (Restless's cross-continental spy chase). Boyd's fiction sits at the intersection of two trends in contemporary fiction. Literary reworking by authors such as Ian Rankin, Denise Mina, and Liam McIlvanney has given cultural capital and prestige to previously "popular" forms such as the historical novel, the detective novel and the thriller, dusting off from them the taint of the Large Print section and the marketplace. Meanwhile, the expansion of higher education over the past decades, combined with the exhaustion of high modernism's project of difficult, demanding, world-changing fiction, has helped foster an audience keen to respond to the flattery of intellectual references without needing to endure their challenge. This is the era of the middlebrow, and Boyd's fictions provide it historical novelty. ${ }^{20}$

Nowhere are the novels' status as consumer items more apparent than in their descriptions of food. Boyd, in the 2000s, has developed a kind of Sunday supplement or in-flight magazine prose style, with descriptions of food and other consumer items forming each text's libidinal centre. What Raphael Samuel called the "conspicuous display of good taste" replaces, in these novels, the development of an aesthetic, an outlook, a way of seeing: tell don't show is these novels' slogan. ${ }^{21}$ No meal goes unnarrated or undescribed, no cooking method unlisted ("red-wine vinegar, chopped shallots, black pepper and lemon juice with a roundel of 
cold-buttered bread to follow"), ${ }^{22}$ no order uncatalogued ("malouf stuffed cabbage rolls-followed by shish tawook-a simple chicken kebab with salty pickles"). ${ }^{23}$ Food makes otherwise buttoned-down prose break out: "the sausage is delicious: hot, shouting with pepper and garlic_-and irresistible". ${ }^{24}$ Whereas, in the usual cliché, talking about food is a substitute for talking about sex, with Boyd sex is an excuse for still more listing and detailing of memorable meals:

They both knew exactly what was going to happen later and that knowledge provided a satisfying sensual undercurrent to their conversation as they ate the meal she cooked for him-a rare sirloin steak with a tomato and shallot salad, the wine a light and fruity Chianti, with a thin slice of lemony torta della nonna to follow. ${ }^{25}$

This is prose that would not be out of place in a Harrods catalogue or one of Nigella Lawson's collection of recipes: "a sudden need for Italian food: Italian food of a simple, honest, basic sortinsalata tricolore, pasta alle vongole, scallopine al limone, torta di nonna". ${ }^{26}$ Some sort of an endpoint is reached in Solo when, just before the novel's climactic scenes, a footnote is introduced to give the reader the recipe for "James Bond's Salad Dressing.", Bertolt Brecht used the metaphor of "culinary theatre" to describe works he saw as offering intellectual snacks and sweets instead of challenges to their audiences. Boyd's recent writing literalises this metaphor. Boyd's novels flatter their readers; for all the high seriousness on display in the subject matter, the sentences themselves will never ask more of their reader than the demands of a detailed restaurant menu.

These culinary blends of "literary" and "genre" fiction involve having one's cake and eating it, setting up a character to refer to the "Zembla files" while also telling readers he was "very aware of its thriller-esque pretensions". ${ }^{28}$ Boyd's preference for first-person narrators and third-person narrators willing to offer something between reported thought and free indirect discourse produces, in his recent fiction, curious kinds of slackness, sentences 
that exist somewhere between a writer negotiating knowingly with bad writing and bad writing itself. "My God," the narrator inflects Bond, "who could predict when your past would suddenly blunder into your life?" Another character is described as entering "the fraught and dangerous world of pure speculation". An escape plan is described-to a character and the reader-in explicit (and textual) detail before the narrator tells us that "Lysander picked up the sub-textual message". Clichés proliferate: "never had the word 'bombshell' seemed more apt"; "revenge is a dish best served cold", "a toothless old mamy" and a "witch doctor" wait in darkest Africa. ${ }^{29}$ True to his principles of recycling, scenes, plot-lines and incidents recur across and between novels: war work spreading media misinformation in Any Human Heart and Restless, incarceration in Switzerland in Any Human Heart and Waiting for Sunrise, the Red Army Faction in Restless and Any Human Heart, explanations for betrayal in Waiting for Sunrise and Restless. Like baby-boomer rock stars touring on old material across the decades, Boyd novels revisit and rework past selves. A favoured phrase will be redeployed, a familiar message ("this complicated, difficult, mortal life we lead") ${ }^{30}$ reused elsewhere.

The vision these novels communicate is, along with the best contemporary English fiction, and in the tradition of Greene, "humane, enlightened, and morally serious." 31 It is also, along with many of his English contemporaries, quite without any sense of wider social forces, of class conflict and class inequality, of imaginative life outside of a quite remarkably provincial, and restricted, geographic and social range. Boyd is an avowed "Sloane Ranger":

I live in Chelsea. I know the neighbouring "villages" of Fulham, South Kensington, and Knightsbridge well, very well indeed ... To the north ... lie places that are wholly alien and strange ... Here in north London the buildings look darker, sootier, in less good repair. The streets seem more narrow, the people scruffier, the pavement littered and soiled ... It is not so much that I have crossed a topographical frontier, it 
is more of a psychological barrier that separates me from these other areas. ${ }^{32}$

Attempts to imagine himself beyond the narrow confines of uppermiddle-class life are usually disastrous. Boyd has neither the political sophistication nor the creative ability to imagine class relations or lives outside of the world of wealth, and when his novels try to evoke something beyond the Chelsea of the mind they end up revealing the awkward situation of his implied reader. Part of the action of Ordinary Thunderstorms takes place on the Shaftesbury Estate, a depressed area of social deprivation. The narrator introduces a (fictional) architect and their heritage via the Estate to the reader: it is "austerely sculptural—exactly the aim and purpose that the architect, Gerald Golupin (1898-1969) had in mind as he had drawn up his visionary design for this complex of social housing." A paragraph on the narrator will tell us that "Mhouse, of course, was thinking none of these thoughts as she plodded up the stairs to her flat". ${ }^{33}$ But why of course? Simple snobbery may be one explanation, the poor - their lives being nasty, Brutalist, and short—not being expected to think about architectural theory. But this is undercut by the mock-catalogue detail of listing the architect's birth and death in parentheses, making clear that the reader could not bring any of this effortlessly to mind either. The novels present a mimesis of erudition-or a simulation of the feeling of being well-read or educated ("I had been reading Taine, for some forgotten scholarly reason" $)^{34}$ - without the demands of actual learning or the challenge of genuine stimulation. They are consumer objects for a "post-ideological" middle class, reassurances of one's learning and social status that will not discomfort as diversions during a flight or commute home.

Is this, then, where the contemporary British wing of the Scottish novel is at? It is one destination, certainly, and an uncertainty of placing-where is the literary in British literary fiction? where is the Britishness?-plays out also in Boyd's aversions to endings. The novels stop rather than finish, their collection of chapter-turning surprises and shock revelations having run out. Denying the satisfactions of narrative in stories made up of some of the most improbable and action-packed of narrative 
reversals is a stock Boydian device: “isn't this how life turns out, more often than not? It refuses to conform to your needs-the narrative needs that you feel are essential to give rough shape to your time on this earth". "The more I seemed to know," the narrator of Waiting for Sunrise tells us, "the more clarity and certainty dimmed and faded away". "As "As I stand here on my modest beach," John James Todd ends The New Confessions, "waiting for the future, watching the waves roll in, I feel a strange, light-headed elation. After all, this is the time of Uncertainty and Incompleteness". ${ }^{37}$ That ironic capitalisation offers a double distancing here, as the novel that contains Todd's autobiography sets itself apart from more straight-faced announcements of the Age of Uncertainty. But the gap remains nonetheless.

Bond, the narrator of Solo tells us, admired another character for "his futile ambitions, his sacrifice, his crazy integrity". 38 Boyd's recent fiction wants the futility and the ambition. He writes from within a tradition of literary fiction that seems no longer certain of its place, audience, or address, but without that certainty hampering the tradition's continuity. There is more to come. And we will be well fed-"cheese soufflé, lamb shank with pommes dauphinoises, strawberries with champagne sorbet ${ }^{33}$ —as we continue our descent. ${ }^{40}$

\section{Notes}

1 On this process see Robert Crawford's classic Devolving English Literature (Oxford: Clarendon, 1992) and, on contemporary developments, Scott Hames, "The New Scottish Renaissance?" in Peter Boxall and Bryan Cheyette (eds.) The Oxford History of the Novel in English, vol. 7 (Oxford: Oxford University Press, 2016).

2 William Boyd, Restless (London: Bloomsbury, 2006), 1, hereafter abbreviated as $R$. For Boyd's other novels, the following editions have been used, and quotations will appear with abbreviations as follows: The New Confessions (NC) (New York: Morrow, 1988). Blue Afternoon (BA) (London: Penguin, 1993). Nat Tate: An American Artists 1928-1960 (NT) (London: Bloomsbury, 1998). Any Human Heart (AHH) (London: Penguin, 2003). The Dream Lover: Short Stories (DL) (London: 
Bloomsbury, 2008). Ordinary Thunderstorms (OT) (London: Bloomsbury, 2009). Waiting for Sunrise (WFS) (London: Bloomsbury, 2012). Longing (L) (London: Bloomsbury, 2013). Solo (S) (London: Jonathan Cape, 2013). Sweet Caress (London: Bloomsbury, 2015) reheats Any Human Heart's leftovers, and is thus incidental to my argument in this essay.

3 See Robert J. C. Young, The Idea of English Ethnicity (Oxford: Blackwell, 2008).

4 James Wood, "V.S. Pritchett and English Comedy" in Zachary Leader (ed.) On Modern British Fiction (Oxford: Oxford University Press, 2002), 9.

${ }^{5}$ OT, 224, AHH, 117, WFS, 13, S, 61 .

6 Tony Bennett and Janet Woollacott, Bond and Beyond: the Political Career of a Popular Hero (New York: Methuen, 1987), 20, 28.

7 William Boyd, Bamboo: Non-Fiction 1978-2004 (London: Hamish Hamilton, 2005), 98.

8 Jean-François Lyotard, The Postmodern Condition: A Report on Knowledge, trans. Geoff Bennington and Brian Massumi (Manchester: Manchester University Press, 1984), xxiv.

9 AHH, 362, WFS, 254, R, 200, S, 222, OT, 40, NC, 154, BA, 199.

${ }^{10} \mathrm{AHH}, 7$. These in turn recycle a character - Logan Mountstuart - and a form from earlier short stories, with "Extracts from the Journal of Flying Officer J" (first published in Giles Gordon, ed. Shakespearean Stories, London: Hamish Hamilton, 1981) and "Hotel de Voyageurs" testing out the fictional journal and the Mountstuart character respectively.

$11 \mathrm{DL}, 5$.

${ }^{12}$ Northrop Frye, Spiritus Mundi: Essays on Literature, Myth and Society (Bloomington: Indiana University Press, 1976), 124.

${ }^{13} N T, 12$.

$14 \mathrm{AHH}, 317$. There is a further twist to the story: in 2011 a painting by Nat Tate, "Bridge 11" was sold at auction in London for over $£ 7000$. Boyd was later revealed as the artist. See Maeve Kennedy, "Painting by mythical artist Nat Tate sells for very real $£ 7250$ at Sotheby's" The Guardian, 16 November 2011.

15 Edmund Gordon, "A Very Modern Man," London Review of Books 34: 5(8 March 2012): 31.

16 Jerome de Groot, The Historical Novel (London: Routledge, 2010), 1.

17 WFS, 88.

${ }^{18}$ WFS, 133. 
19 Henry James, "Preface" to The Aspern Papers (New York Edition of the Novels of Henry James), vol. 12, 1908, x.

20 Here by all means see Gabriel Josipovici, What Ever Happened to Modernism? (New Haven: Yale University Press, 2010).

${ }^{21}$ Quoted in Alex Callinicos, "The 'New Middle Class' and Socialists," International Socialism 2: 20 (Summer 1983): 4.

22,15 .

$23 \mathrm{~S}, 64$.

$24 \mathrm{AHH}, 37$.

${ }^{25} S, 206$.

26 OT, 3 .

27 Interested readers should consult Solo, 269. The vinaigrette has amorous properties, without similarly elevating the prose: "His culinary hunger assuaged, a new one replaced it. He was hungry for Blessing, for her slim active body. Hungry for her to give him more precise instructions about what she wanted him to do to her." (269)

28 OT, 313 .

${ }^{29} S, 217, S, 238, W F S, 108, R, 31, S, 213,108,113$.

30 OT, 403.

31 Terry Eagleton, The English Novel: An Introduction (Oxford: Blackwell, 2005), 337.

32 Bamboo, 58.

33 OT, 99.

${ }_{35}^{34} R, 3$.

35 AHH, 295.

${ }^{36}$ WFS, 345.

${ }^{37} N C, 528$.

${ }^{38} \mathrm{~S}, 44$.

39 OT, 141

40 My thanks to the IRSS's two anonymous reviewers for their insightful criticisms of an earlier, looser, version of this argument, and to James Acheson and Sarah Ross, without whom this essay would not have been written. 